\title{
KNOWLEDGE AND PRACTICE RELATED TO THE PAP SMEAR TEST AMONG CYTOPATHOLOGISTS
}

\author{
Camila Aparecida Pinheiro Landim ALMEIDA ${ }^{1}$ (D), Andressa Brandão dos SANTOS ${ }^{2}$ (D), \\ Jessica Aguiar de ALENCAR ${ }^{2}$ (i) , Antonio Luiz GOMES JÚNIOR² (iD), Herica Emilia Félix de CARVALHO ${ }^{3}$ (D), \\ Eliana Campêlo LAGO ${ }^{4}$ (D) Carmen Viana RAMOS ${ }^{5}$ (D) , Lucíola Galvão Gondim Corrêa FEITOSA 5 (i)
}

${ }^{1}$ Institute of Health Sciences, Universidade Católica Portuguesa, Porto, Portugal.

2 Department of Biomedicine, UNINOVAFAPI University Center, Teresina, Piauí, Brazil.

3 Postgraduate Program in Fundamental Nursing, University of São Paulo, Ribeirão Preto, São Paulo, Brazil.

${ }^{4}$ Department of Health Sciences, State University of Maranhão, Caxias, Maranhão, Brazil.

${ }^{5}$ Professional Master's Program in Family Health, UNINOVAFAPI University Center, Teresina, Piauí, Brazil.

Corresponding author:

Camila Aparecida Pinheiro Landim Almeida

Email: clalmeida@porto.ucp.pt

How to cite: ALMEIDA, C.A.P.L, et al. Knowledge and practice related to the pap smear test among cytopathologists. Bioscience Journal. 2021, 37, e37026. https://doi.org/10.14393/BJ-v37n0a2021-44205

\begin{abstract}
Cervical cancer is the third most common type of cancer amongst women, compared to other neoplasms, with a higher potential for prevention, slow evolution, and has a simple and effective screening test in its detection, cure when diagnosed early. The routine examination in Brazil for the prevention of this type of cancer is the Pap smear test. This study aimed to reveal the knowledge and practice regarding the Pap smear test among cytopathologists. A descriptive and exploratory research, a qualitative approach, performed with 21 cytopathologists, by e-mailing a data collection instrument, from March to April 2018. Data were treated using the Hierarchical Descending Classification in IraMuTeQ software and analyzed by the Discourse of the Collective Subject. The construction of the results was carried out based on aspects of the knowledge of the cytopathologists about the Pap smear, related to the importance of the completion of the post-graduation for its accomplishment, and aspects of cytopathologists practice regarding the relevance of performing the early diagnosis of cervical cancer. We conclude on the need to reorganize the activities in the work process of the health professionals involved in the Pap smear.
\end{abstract}

Keywords: Disease Prevention. Health Personnel. Papanicolaou Test. Uterine Cervical Neoplasms.

\section{Introduction}

In a worldwide analysis, approximately $84 \%$ of all cervical cancers (WC) and $88 \%$ of all deaths caused by WC occurred in countries with fewer resources (ie those with a human development index (HDI) $<0.80$ ), of which $1.8 \%$ of women were diagnosed and $1.3 \%$ died of the disease before the age of 75 , in the absence of competing causes of death. It was also observed that the variations in rates are more impressive when the focus is on the subcontinents. Overall, the lowest incidence burden was seen in West Asia and the lowest mortality burden was observed in Australia. The highest load was seen in Southern Africa and East Africa. China was the country with the highest number of cases, 106,000 cases, while India was the country with the highest estimated number of deaths from cervical cancer with 60,000 (Arbyn et al. 2020).

$\mathrm{CC}$ is the third most common cancer among women, estimates for Brazil in the 2018-2019 biennium are 16,370 new cases, with an estimated risk of 15.43 cases per 100,000 women. Compared to other neoplasms, it is one of the types of cancer that has the greatest potential for prevention, with slow evolution 
and simple and effective screening test, as well as a cure when diagnosed early (INCA - Instituto Nacional de Câncer 2018).

Human Papillomavirus (HPV) infection has been considered the most prevalent Sexually Transmitted Infection (STI) in the world, detected in almost $100 \%$ of cases of already registered CC. This incidence increases in women infected with acquired immunodeficiency syndrome (AIDS/HIV), where the body's immunity will mark below normal average, increasing the chances of acquiring neoplasia (Boda et al. 2018).

The importance of detecting possible lesions by cytopathological examination is mainly for the prevention of $\mathrm{CC}$, since it is considered the safest and most effective method for the sexually active female population, the Ministry of Health, through INCA, Brazil, cytological examination (Papanicolaou) should be performed annually in women between 25 and 64 years of age or, even before this age in those with a history of sexual intercourse (Oliveira et al. 2018).

Research states that risk factors for CC development include: life habits such as smoking, early initiation of sexual activity, multiple sexual partners, poor ingestion of essential vitamins, prolonged use of oral contraceptives, and some types of STDs, related factors genetics and immune response (Šarenac and Mikov 2019).

Despite being the most appropriate, practical and low-cost method for CC screening, adherence to the exam is still far from the coverage recommended by the Ministry of Health. Some factors for noncompliance are associated with absence of symptoms, lack of knowledge about the disease, fear, as well as socioeconomic and cultural conditions. It is necessary to identify the knowledge and practice of the exam to establish goals emphasizing importance and contributing to its comprehensiveness in society (Carvalho and Jurado 2018).

It should be emphasized that the primary care services should seek to know the reality, difficulties and barriers of each coverage sector that leads women not to perform the Pap smear because once the problems are identified, alternatives can be applied to increase the coverage of the exam (Fernandes et al. 2019).

In this sense, due to the importance of the early detection of the CC and the accomplishment of the cytopathological examination, the relevance of the health professionals in the knowledge and practice of this examination stands out. Thus, cytopathologists are health professionals who are potentially capable of guiding and preventing CC, and scientific studies on the knowledge and practice related to the pap smear test among these professionals are essential.

In view of this context, it was necessary to carry out the present study, which aimed to reveal the knowledge and practice regarding the Pap smear test among cytopathologists.

\section{Material and Methods}

This is a descriptive and exploratory research, with a qualitative approach, selected to apprehend pertinent characteristics of the human conception related to the object of this study: knowledge and practice regarding the Pap smear test among cytopathologists.

The scenario of this research was developed in a virtual environment (internet), because the participants were invited via email and all stages of data production were developed online.

The participants of the study were cytopathologists with a postgraduate degree in "Clinical, Gynecological and Oncotic Cytopathology" of a Higher Education Institution (IES), located in Teresina, Piauí, Brazil. The choice to develop this study especially with post-graduate cytopathologists by this IES was intentional, since it is a reference in the Brazilian state of Piauí, as a center of excellence in higher education, reaffirming the quality of teaching, as well as the contribution of the Institution to raise the quality standard in the training of professionals for the State of Piauí.

To carry out the selection of the participants of this study, the following inclusion criteria were established: being a health professional, having completed a postgraduate course in Clinical, Gynecological and Oncotic Cytopathology and making available to the procedures and period of data collection (February and March 2018), after clarification of all stages of the research. Participants who did not respond within the deadlines determined for the study were excluded. After defining the inclusion and exclusion criteria, 21 cytopathologists participated in the study. The theoretical saturation of the answers was considered when there was no more possibility of providing elements to mark or deepen theorization (Minayo 2017). 
To obtain the data, we used an instrument composed of a questionnaire elaborated by the researchers with sociodemographic aspects and related to the academic and professional formation, in addition to a script with three subjective questions.

The data were obtained by sending a letter of invitation, via e-mail, clarifying the purpose of the study after the acceptance of the cytopathologists in collaborating with the study. Then, the Informed Consent Form (ICF) and the instruments of data collection were sent.

The software IRaMuTeQ (acronym of Interface of Multi-Dimensional Analyzes of Textes et de Questionnaires) was used to process the data. It was decided to use software in this stage, based on the increasing use of this resource in studies with qualitative approach in the last years, mainly due to the transparency and systematics conferred to the process in this case. Nevertheless, it is worth noting that its use is not a method of data analysis, but rather an auxiliary procedural tool, being the interpretation and naming of classes to the researcher. Data were treated using the Descending Hierarchical Classification (DHC) method as guided by previous studies. In this method, textual corpus (interviews texts) are classified according to their vocabularies, and the set of these is divided by the frequency of the reduced forms, to obtain a stable and definitive classification (Kami et al. 2016).

The discussion of DHC findings, together with cytopathologists' statements, was subsidized in the Discourse of the Collective Subject (DCS), which consists of a qualitative way of representing collective thought, adding similar discursive contents emitted by different people to the speech synthesis. Thus, each participant interviewed, selected based on criteria of social representativeness, contributes with a fragment of thought to the collective thought. The DCS technique consists in selecting from each individual answer to a question the central ideas $(\mathrm{Cl})$, which are the synthesis of the discursive content manifested in the discourses-synthesis, which are the DCS, where the thought of a group or collective it appears as an individual discourse (Lefèvre et al. 2009; Kami et al. 2016; Sousa et al. 2016; Queiroz and Sousa 2017; Medeiros et al. 2019)

The inclusion of the participants in this study was performed according to the ethical-legal recommendations that govern the research with human beings (Brasil 2012). All participants were informed about the purpose and methods of the study and signed the Free and Informed Consent Form. As a way of preserving anonymity, the names of the cytopathologists participating in this study were replaced by the capital letter C, followed by Arabic numerals: C1, C2, C3 ... C23.

The research was approved by the Research Ethics Committee of the Higher Education Institute of Piauí, in compliance with Resolution 466/12 of the National Health Council, under the Certificate of Presentation and Ethical Assessment and Opinion no 2.409.538, on December 1, 2017.

\section{Results}

Out of the 21 cytopathologists participating in this study, 13 (61.9\%) were female, with a mean age of 25 years, 17 (80.9\%) were single and with a minimum time of completion of postgraduate studies in cytopathology at one year.

The IRaMuTeQ recognized the separation of the corpus into 134 Elementary Context Units (ECU) and six classes, using $83 \%$ of the total corpus, a figure considered sufficiently high for the analysis. The corpus obtained an axis, which emerged in class 6, with 25 ECU (18.66\%), being subdivided in class 5, with 23 ECU (17.16\%), and two branches, classes 1, with 21 ECU (15.67\%), and 4, with 20 ECU (14.93\%) and then classes 3, with 23 ECU (17.16\%) and 2, with 22 ECU (16.42\%). By the technique of the Descending Hierarchical Classification, it was possible to identify knowledge and practice, through the interpretation of the speeches of cytopathologists, appointed in their respective directions in the six classes obtained in the dendrogram (Figure 1).

The six classes in this study listed the knowledge and practice regarding the Pap smear test among cytopathologists, and revealed that classes 6, 5, 1 and 4 were related to knowledge and classes 3 and 2 were related to practice. According to the assumptions of the Discourse of the Collective Subject, each cytopathologist interviewed contributed his share of thought fragment to collective thought. Therefore, after the analysis of the interview transcription, from each central idea, the key expressions were identified, and the discourse of the collective subject was constructed (Lefèvre et al. 2000). 


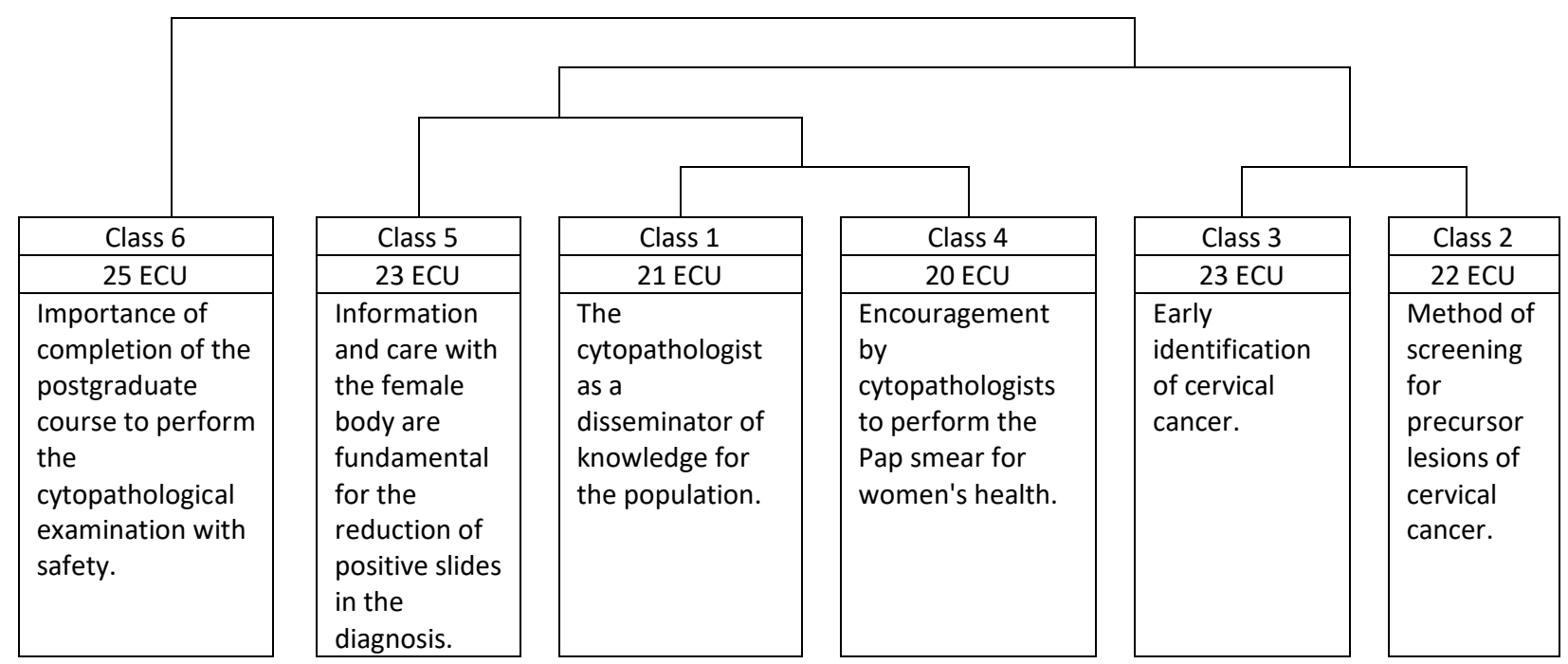

Figure 1. Thematic dendrogram of the knowledge and practice regarding the Pap smear test among cytopathologists. *ECU: Elementary Context Units.

First central idea - Importance of the conclusion of the postgraduate course to perform the cytopathological examination with safety.

Key words:

- Conclusion of the Graduate

- Knowledge and practice in taking the exam

- Trust in diagnosis

- Importance of cytopathologists

- Accurate diagnosis

Discourse of the Collective Subject:

The importance of being a specialist in the field of cytopathologists is to offer a safety in the diagnosis for the conclusion of the report, being of great relevance to acquire knowledge and practice for the cytopathological examination, through knowledge of the alterations, minimizing possible errors, allowing greater confidence in the diagnosis. There is a need for the insertion of trained professionals in different places, as well as in small cities, as it will facilitate for women the accomplishment of this examination and will reduce the waiting time of the result. Accurate diagnoses contribute to the reduction of cases of cervical cancer, as well as possible precursor infections in the female population (C.3, C.4, C.6, C.8, C.10, C.11, C. 15, C.16, C.17, C. 19, C. 21).

Second central idea - Information and care with the female body are fundamental for the reduction of positive slides in the diagnosis.

Key words:

- Risks from lack of care

- Importance of information

- Experts must be aware of

Discourse of the Collective Subject:

Knowing the Papanicolaou exam means knowing about women's health, the possibilities of prevention and the risks involved in the lack of care for women's intimate health. Women need this information to take greater care of their intimate health and sex life, since cervical cancer can be diagnosed from human papillomavirus (HPV) contamination. The specialists can carry out educative campaigns for women in order to pass knowledge, clarify doubts and minimize shyness, since the most important thing is the health of their body (C.4, C.6, C.14, C.17). 
Third central idea - Encouragement by cytopathologists to perform a Pap smear for women's health.

Key words:

- The encouragement of women's health experts

- Dissemination of the examination

- Prevention for cervical cancer

Discourse of the Collective Subject:

It is important for women to be aware of the significance and relevance of a Pap smear, and therefore, the cytopathologist may be essential to encourage the female population to perform this test so that they can your body and adopt a healthy lifestyle. The dissemination of this examination in all municipalities increases the coverage of prevention for cervical cancer, since it can affect anyone, especially women who do not use the screening test (C.3, C.5, C.14, C.17, C.19, C.20).

Fourth central idea - The cytopathologist as a disseminator of knowledge for the female population.

Key words:

- The importance of acquiring knowledge about the exam

- The contribution of experts to obtain accurate results

- Importance of knowledge for the female population

- Early detection

Discourse of the Collective Subject:

The conclusion of the specialization in the area of cytopathology enables these specialists to be professionals capable of clarifying possible doubts and fears existing among women, since the Papanicolaou exam directly invades the intimacy of the woman. It is important for the female population to have as much knowledge as possible about this examination and its periodical realization, so that possible precursor lesions of cervical cancer can be identified, since early detection is the best form of prevention (C.4, C, 12, C.17, C.19, C. 20).

Fifth central idea - Early identification of cervical cancer.

Key words:

- Papanicolaou exam is the best method of prevention

- Detection of neoplastic cells from cervical cancer

- Healing Chances

Discourse of the Collective Subject:

The Papanicolaou exam is offered in the Brazilian public network so that there is a greater coverage in the female population, since it is considered the best method of prevention for cervical cancer, since it diagnoses vaginal infections or infections, besides its low cost and effectiveness. When early detected, cervical cancer has a high chance of progressing to cure. In view of the high degree of mortality and mortality, this cancer presents as a prevention periodic cytopathological examination as indispensable during the woman's life (C.3, C.11, C.13, C.16, C. 17, C.19).

Sixth central idea - A method of screening precursor lesions of cervical cancer.

Key words:

- Distinction of cells and their alterations

- Quality care for women

- Early detection of precursor lesions

- Reports with confidence and precision 
Discourse of the Collective Subject:

The cytopathologist must have enough knowledge about the techniques and be able to distinguish the cells and their alterations, considering the patterns that define the normality of the abnormality. Providing excellent care to women means accompanying all stages of the examination from the cytopathological collection procedure to the preparation of the slides to ensure that there are no errors and fewer falsenegative diagnoses. The clinical eye of the cytopathologist is indispensable for the real identification of altered cells, with greater possibility of releasing the reports with confidence and precision (C.3, C.12, C.14, C.15, C. 16).

\section{Discussion}

The study allowed to reveal aspects of the knowledge of the cytopathologists about the Pap smear, related to the importance of the conclusion of the post-graduation for the accomplishment of the cytopathological examination with safety. Considering that the information and the care with the female body are fundamentals for the reduction of positive specimens in the diagnosis of cervical cancer. It was also possible to reveal that the cytopathologist is considered a professional capable of encouraging the Papanicolaou test, as a disseminator of knowledge for the female population.

Research revealed that one of the items recommended by the Bethesda System, international standardization used to classify neoplasms, is the report in the sample suitability as an important component to guarantee the quality of the smear, since most false negative results occur due to the failure to obtain mistaken interpretations, false positives or false negatives (Oliveira et al. 2015). Thus, it is important the cytopathologists to act more confidently in the diagnosis.

In agreement with the study of Navarro et al. (2015) it is necessary that the professionals are qualified to guide the women, in order to better explore the female profile, with knowledge regarding the examination and the limitations for its realization, so that they know such as increasing adherence to the preventive method by the population, thus reducing the high morbidity and mortality rate of cervical cancer due to failure to perform the Pap test.

The discourses in this study revealed that the specialist should adequately guide women about methods of prevention against cervical cancer, which could reach as many women as possible. In the process of indispensable guidelines to be given, it is important to emphasize the relevance of the return after receiving the result of the exam and to be re-evaluated by the physician (Silva et al. 2017a).

For the cytopathologist to act as a coadjuvant agent, it is necessary to have a good relationship with the women, in addition to the preparation of the slides, and also to work on sociocultural issues that may influence noncompliance with the Pap smear, in order to break taboos and prejudices about the procedure and purpose of the examination. Therefore, the accuracy of the diagnosis by the cytopathologist becomes relevant because of specific related knowledge, as found in the central ideas (Santos et al. 2018).

Also, in the speeches found in this study, women's knowledge about the process of health care and promotion is critical in order to reduce the chances of cancerous lesions in the cervix. Actions of early detection of cancer, such as health education, request for exams and guidelines in the treatment of this pathology are some of the activities that the professionals must carry out to guarantee the accomplishment of the Papanicolaou examination by the women for the health prevention (Andrade 2017).

Thus, the women's knowledge about the exam and its importance in the prevention of CC are factors that can contribute to the increase in the adherence of the exam, besides understanding the difficulties related to its accomplishment, collaborating for the implementation of actions that facilitate the women's access to the practice of the exam and the reduction of positive diagnoses (Silva et al. 2017b).

It is important to highlight that professionals play an important role in the dissemination of information about CC and in the accuracy of early diagnosis, especially in the evaluation of the results obtained, in the integration with multiprofessional team and with the community, as it is still a serious health problem in Brazil , mainly due to its persistence in poorer places in the country, where inequalities in living conditions are more evident (Medeiros et al. 2019).

In agreement, the study by Mello et al. (2017) concluded that the lack of regularity in the collection of Papanicolaou examination is pointed out as the main factor that limits the prevention of CC. Thus, health 
education is a strong ally in the prevention of this cancer, stimulating behavior change and promoting the adoption of new habits and health behaviors.

Corroborating this finding, research indicates that reaching women with information is a great challenge, but it is a necessary practice that must be combined with other strategies to facilitate the dissemination of knowledge and the practice of care in this population in a more intense way (Vasconcelos et al. 2017).

According to the fourth central idea, this study revealed that the dissemination of knowledge by cytopathologists about the Pap smear for the female population is important because they are specialists in this type of examination. In this context, this health professional is considered capable of propagating the relevance of this examination, providing ways for women to practice cervical cancer prevention, since the cytopathological examination is considered as a preventive and diagnostic of CC (Farias and Barbieri 2016).

Knowledge must be of universal access for all women, regardless of socioeconomic class, to perform the preventive examination for CC. In view of this, the cytopathologist should be able to promote knowledge, especially for women, who present greater risk factors for acquiring sexually transmitted infections. It is very necessary to perform this periodic cytopathological examination to prevent diseases that affect the intimate health of women (Audi et al. 2016).

The fact that CC is directly related to HPV infection, this virus can mainly affect women who engage in sexual activity without the use of condoms. This is mainly due to the lack of knowledge of these women regarding sexually transmitted infections, however, in agreement with the discourse revealed in this study, specialists in cytopathology can act in the propagation of information that help women to be more active in the prevention of cancer of the cervix (Trindade et al. 2017).

This study also revealed aspects of cytopathologists' practice regarding the Pap smear, related to the relevance of early diagnosis of cervical cancer, as well as to identify screening methods for precursor lesions of this cancer.

Cancer of the uterine cervix is considered one of the types with higher incidence of cure, when detected early by Papanicolaou. Preventive examination is considered one of the most effective methods to investigate possible precursor lesions of CC. It is necessary to perform it periodically to reduce the incidence of this type of cancer (Campos et al. 2017).

Papanicolaou exam began to be implemented for the prevention of women since the late nineteenth century, before that, techniques used to combat cervical cancer were radical and were based on the total withdrawal of the uterus and cervix. Thus, the Papanicolaou test aims to guarantee a reliable efficacy in the prevention of women's health, being of fundamental importance for a reliable diagnosis (Teixeira 2015).

This study shows that there are many barriers faced by women for not performing the Pap test, including lack of knowledge as one of the primary factors, causing the need for insertion of educational programs aimed at clarifying existing doubts about the preventive exam and (Carvalho and Jurado 2018). In the present study, it is possible to estimate the number of women in the sample.

According to the study by Manfredi et al. (2016), it is necessary that there is a priority in attention to adolescents before the cytopathological examination, because the lack of knowledge of this public also causes the low adhesion of the exam. This importance mainly occurs because this age group is more propitious the lack of knowledge about sexually transmitted infections, thus favoring the installation of HPV, with evolution to cervical cancer.

It was possible to relate in the speeches that the proper practice of the cytopathologists on the accomplishment of the Papanicolaou examination is of paramount importance, considering that a reliable result depends directly on the care in the production of each stage, from the preparation of the woman in the collection until the confection of the blades and material analysis. Research revealed that the cytopathologist should be able and competent to participate in all stages of the Pap smear (Kumar et al. 2020).

The limitations of the study are related to the type of study that does not give us the possibility to accompany these professionals during the exam, however, the evidenced information responded to the proposed objectives; and the type of data collection that was via e-mail, there was a difficulty in getting answers, however, because they are busy professionals and in full exercise of their profession this was the most viable choice. 


\section{Conclusions}

The present study made it possible revealing aspects of cytopathologists' knowledge about the Pap smear, related to the importance of the conclusion of the post-graduation for its safety, considering that the cytopathologist is a professional capable of encouraging the cytopathological examination as a disseminator knowledge for the female population. This study also revealed aspects of cytopathologists' practice regarding the relevance of performing early diagnosis of cervical cancer, as well as identifying screening methods for precursor lesions of this cancer.

In view of the discourses revealed by the cytopathologists, this study indicates the need to reorganize activities in the work process of the health professionals involved with the Pap smear, mainly through the need to carry out educational activities, which allow the interaction between women and the health professionals, in the perspective of greater consolidation of local and national public policies of integral attention to the prevention of women's health.

Other researches are still necessary, especially randomized clinical trials, with the objective of making the knowledge accessible to the scientific community and, enabling health professionals, especially cytopathologists, to contribute to improving health care for the female population.

Authors' Contributions: ALMEIDA, C.A.P.L.: conception and design, acquisition of data, analysis and interpretation of data, drafting the article; SANTOS, A.B. and ALENCAR, J.A.: acquisition of data, analysis and interpretation of data, drafting the article; GOMES JÚNIOR, A.L. and CARVALHO, H.E.F.: analysis and interpretation of data, drafting the article; LAGO, E.C.; RAMOS, C.V. and FEITOSA, L.G.G.C.: drafting the article. All authors have read and approved the final version of the manuscript.

Conflicts of Interest: The authors declare no conflicts of interest.

Ethics Approval: Approved by Research Ethics Committee of Higher Education Institute of Piauí. Number: 2.409.538.

Acknowledgments: Not applicable.

\section{References}

ANDRADE, V.R.M. Interdisciplinaridade como instrumento educativo em saúde: um estudo sobre o câncer de colo do útero. Revista Brasileira De Análises Clínicas. 2017, 49(2), 189-94. https://doi.org/10.21877/2448-3877.201700541

ARBYN, M., et al. Estimates of incidence and mortality of cervical cancer in 2018: a worldwide analysis. The Lancet Global Health. 2020, 8(2), 191-203. https://doi.org/10.1016/S2214-109X(19)30482-6

AUDI, C.A.F., et al. Inquérito sobre condições de saúde de mulheres encarceradas. Saúde em debate. 2016, 40(109), 112-124. https://doi.org/10.1590/0103-1104201610909

BRASIL. Resolução no 466, de 12 de dezembro de 2012. Diretrizes e normas regulamentadoras de pesquisas envolvendo seres humanos. Diário Oficial da União da República Federativa do Brasil, 12 dez. 2012. Available from:

https://bvsms.saude.gov.br/bvs/saudelegis/cns/2013/res0466_12_12_2012.html

BODA, D., et al. Human papilloma virus: Apprehending the link with carcinogenesis and unveiling new research avenues (Review). International Journal of Oncology. 2018, 52(3), 637-55. https://doi.org/10.3892/ijo.2018.4256

CAMPOS, E.A., CASTRO, L.M., CAVALIERI, F.E.S. "Uma doença da mulher": experiência e significado do câncer cervical para mulheres que realizaram o Papanicolau. Interface - Comunicação, Saúde, Educação. 2017, 21(61), 385-96. https://doi.org/10.1590/1807-57622016.0159

CARVALHO, L.R.S. and JURADO, S.R. Motivos que influenciam a não realização do exame de Papanicolaou. Revista Recien. 2018, 8(23), 39-46. https://doi.org/10.24276/rrecien2358-3088.2018.8.23.39-46

FARIAS, A.C.B. and BARBIERI, A.R. Seguimento do câncer de colo de útero: Estudo da continuidade da assistência à paciente em uma região de saúde. Escola Anna Nery. 2016, 20(4), 1-12. https://doi.org/10.5935/1414-8145.20160096

FERNANDES, N.F.S., et al. Acesso ao exame citológico do colo do útero em região de saúde: mulheres invisíveis e corpos vulneráveis. Cadernos de Saúde Pública. 2019, 35(10), 1-12. https://doi.org/10.1590/0102-311x00234618

INCA. Instituto Nacional de Câncer José Alencar Gomes da Silva. Coordenação de Prevenção e Vigilância. Estimativa 2018: incidência de câncer no Brasil. Rio de Janeiro: INCA, 2018. Available from: https://portaldeboaspraticas.iff.fiocruz.br/biblioteca/estimativa-2018-incidencia-decancer-no-brasil/

KAMI, M.T.M., et al. Working in the street clinic: use of IRAMUTEQ software on the support of qualitative research. Escola Anna Nery. 2016, 20(3), 1-12. https://doi.org/10.5935/1414-8145.20160069

KUMAR, N., GUPTA, R. and GUPTA, S. Inadequate clinical data on Pap test request form: Where are we headed in the era of precision medicine? CytoJournal . 2020, 17(1), 1-15. https://doi.org/10.25259/Cytojournal 872019 
LEFÈVRE, F., LEFÈVRE, A.C. and TEIXEIRA, J.J.V. O discurso do sujeito coletivo: uma nova abordagem metodológica em pesquisa qualitativa. Caxias do Sul: EDUCS, 2000.

LEFÈVRE, F., LEFÈVRE, A.M.C. and MARQUES, M.C.C. Discurso do Sujeito Coletivo, complexidade e auto-organização. Ciência \& Saúde Coletiva. 2009, 14(4), 1193-204. https://doi.org/10.1590/S1413-81232009000400025

MANFREDI, R.L.S., et al. Exame Papanicolou em gestantes: conhecimento dos enfermeiros atuantes em unidades de atenção primária à saúde. Revista de Pesquisa: Cuidado é Fundamental Online. 2016, 8(3), 4668-673. https://doi.org/10.9789/2175-5361.2016.v8i3.4668-4673

MELLO, F.A., GALLE, L.C. and PRADO, R.L. Prevenção do câncer de colo uterino na concepção da população feminina de uma cidade do interior do estado de São Paulo. Coloquium Vitae. 2017, 9(2), 45-52. https://revistas.unoeste.br/index.php/cv/article/view/1317

MEDEIROS, F.K.F., et al. A Percepção dos estudantes de enfermagem sobre o exame Papanicolau para diagnóstico das doenças ginecológicas. Revista de Pesquisa: Cuidado é Fundamental Online. 2019, 11(5), 1167-72. http://dx.doi.org/10.9789/2175-5361.2019.v11i5.1167-1172

MINAYO, M.C.S. Amostragem e saturação em pesquisa qualitativa: consensos e controvérsias. Revista Pesquisa Qualitativa. 2017, 5(7), 1-12. https://redib.org/Record/oai articulo1169759

NAVARRO, C., et al. Cobertura do rastreamento do câncer de colo de útero em região de alta incidência. Revista de Saúde Pública . 2015, 49(17), 1-8. https://doi.org/10.1590/S0034-8910.2015049005554

OLIVEIRA, E.S., et al. Citopatologia cervical e perfil epidemiológico de mulheres com vida sexual ativa. Revista de Enfermagem UFPE on line. 2015, 9(7), 8985-92. https://doi.org/10.5205/reuol.8074-70954-1-SM0907supl201507

OLIVEIRA, M.M., et al. Cobertura de exame Papanicolaou em mulheres de 25 a 64 anos, segundo a Pesquisa Nacional de Saúde e o Sistema de Vigilância de Fatores de Risco e Proteção para Doenças Crônicas por Inquérito Telefônico, 2013. Revista Brasileira de Epidemiologia. 2018, 21(1), 1-10. https://doi.org/10.1590/1980-549720180014

QUEIROZ, A.A.F.L.N., and SOUSA, A.F.L. Fórum PrEP: um debate on-line sobre uso da profilaxia pré-exposição no Brasil. Cadernos de Saúde Pública. 2017, 33(1), 1-12. https://doi.org/10.1590/0102-311x00112516

SANTOS, A.S., et al. Tecnologia educacional baseada em nola pender: promoção da saúde do adolescente. Revista de Enfermagem UFPE on line. 2018, 12(2), 582-8. https://doi.org/10.5205/1981-8963-v12i2a22609p582-588-2018

ŠARENAC, T., and MIKOV, M. Cervical Cancer, Different Treatments and Importance of Bile Acids as Therapeutic Agents in This Disease. Frontiers in Pharmacology. 2019, 10(1), 1-12. https://doi.org/10.3389/fphar.2019.00484

SILVA, A.B.S., et al. Prevenção do câncer cervicouterino: uma ação realizada pelos enfermeiros da estratégia saúde da família? Revista Ciência plural. 2017a, 3 (2), 99-114. https://periodicos.ufrn.br/rcp/article/view/12926/8993

SILVA, L.R., et al. Educação em saúde como estratégia de prevenção do câncer do colo do útero: revisão integrativa. Revista Prevenção de Infecção e Saúde. 2017b, 3(4), 35-45. http://www.ojs.ufpi.br/index.php/nupcis/article/view/6708

SOUSA, Á.F.L, et al. Social representations of biosecurity in nursing: occupational health and preventive care. Revista Brasileira de Enfermagem. 2016, 69 (5), 864-871. https://doi.org/10.1590/0034-7167-2015-0114

TEIXEIRA, L.A. Dos gabinetes de ginecologia às campanhas de rastreamento: a trajetória da prevenção ao câncer de colo do útero no Brasil. História, Ciências, Saúde-Manguinhos. 2015, 22(1), 221-40. http://dx.doi.org/10.1590/\$0104-59702015000100013

TRINDADE, G.B., et al. Avaliação do rastreamento do câncer do colo do útero e sua periodicidade em um município de Santa Catarina. Medicina. 2017, 50(1), 1-10. https://doi.org/10.11606/issn.2176-7262.v50i1p1-10

VASCONCELOS, L.C., et al. Conhecimento de Mulheres a Respeito do Exame Papanicolau. Uniciências . 2017, 21(2), $105-109$.

https://doi.org/10.17921/1415-5141.2017v21n2p105-109

Received: 29 August 2018| Accepted: 18 June 2020 | Published: 10 June 2021

This is an Open Access article distributed under the terms of the Creative Commons Attribution License, which permits unrestricted use, distribution, and reproduction in any medium, provided the original work is properly cited. 